\title{
Comparative Study on Ethanol Production with Pentose and/or Hexose by Saccharomyces cerevisiae and/or Pichia stipitis
}

\author{
Jung-Gon $\mathrm{Kim}^{1}$ and Jung Hoon $\mathrm{Ahn}^{2}$ * \\ ${ }^{1}$ College of Nano Science and Technology, Pusan National University, Busan 609-735, Korea \\ ${ }^{2}$ Korea Science Academy of KAIST, Busan 614-103, Korea
}

Received October 20, 2010/Accepted February 18, 2011

\begin{abstract}
Glucose and xylose are the most abundant materials in nature which can be used to produce ethanol by yeast fermentation. Three combinations of cultivation with glucose and xylose were carried out; separated, co-culture, and sequential fermentation with Saccharomyces cerevisiae and Pichia stipitis. In the separated fermentation, $S$. cerevisiae fermented glucose to produce $14.5 \mathrm{~g} / \mathrm{l}$ ethanol from $29.4 \mathrm{~g} / \mathrm{l}$ glucose but hardly used xylose. However, $P$. stipitis utilized not only glucose but also xylose to produce ethanol $11.9 \mathrm{~g} / \mathrm{l}$ and $11.6 \mathrm{~g} / \mathrm{l}$ from $29.4 \mathrm{~g} / \mathrm{l}$ glucose and $29.0 \mathrm{~g} / \mathrm{l}$ xylose, respectively. In the mixture of glucose and xylose, $P$. stipitis fermented both sugars, producing $21.1 \mathrm{~g} / 1$ ethanol while $S$. cerevisiae fermented only glucose, producing $13.4 \mathrm{~g} / \mathrm{l}$ ethanol. In the $\mathrm{co}^{-}$culture and sequential fermentation, the $\mathrm{co}^{-}$culture showed more efficient ethanol productivity with $18.6 \mathrm{~g} / \mathrm{l}$ ethanol than the sequential fermentation with $12.4 \mathrm{~g} / \mathrm{l}$ ethanol. To investigate the effect of nutrients in the growth of microorganisms and ethanol production, yeast nitrogen base (YNB) was used in the sequential fermentation with $S$. cerevisiae and $P$. stipitis. YNB supplemented some nutrients which $S$. cerevisiae used up in the broth and the culture showed increased growth rate, increased consumption of xylose, and increased ethanol productivity producing $22.5 \mathrm{~g} / 1$ ethanol from $54.6 \mathrm{~g} / 1$ sugar with a yield of $0.41 \mathrm{~g} / \mathrm{g}$.
\end{abstract}

Key words : Ethanol, Saccharomyces cerevisiae, Pichia stipitis, glucose, xylose

\section{Introduction}

The production and use of ethanol for fuel are increasing worldwide in response to economic, security, and environmental concerns. Because ethanol can be easily applied to the internal combustion engine vehicles, it is used as an oxygenate to reduce automotive emissions [19]. In the usage of ethanol, the by-products derived from fossil energy are strongly reduced or even absent with biofuels and it could help avoid accumulation of carbon dioxide causing environmental problems in the atmosphere [6,8,20]. Moreover, other grounds for use of ethanol include the benefits of producing ethanol for farmers and rural economies [19].

Ethanol has been produced mainly by fermenting sugars with yeasts. These sugars were obtained from grains and sugarcane. The United States and Brazil are the world's largest ethanol producers and consumers using corn grain and sugar cane. However, ethanol production using grains and sugarcane has faced a conflict of a food shortage. Fortunately, there are plenty of sugars in nature in the form

*Corresponding author

Tel : +82-51-606-2335, Fax : +82-51-606-2226

E-mail : hoony@kaist.ac.kr of lignocelluloses which is the most abundant material in the wood and consists of cellulose (40\%), hemicelluloses (30\%), and lignin (20\%) in average [21]. Glucose is the major component of cellulose and xylose is a main constituent of hemicelluloses [7,17,21]. Because pretreatment and saccharification of lignocellulosic biomass yields mainly glucose and xylose, it is a big challenging task to ferment two sugars.

Saccharomyces cerevisiae is used widely and traditionally for industrial ethanol production because it is highly effective on the production of ethanol from hexose sugars and has high tolerance to ethanol and other inhibitory compounds [10-12]. Although xylose is the second major fermentable sugars present in hard woods and herbs, xylose cannot be fermented by S. cerevisiae. For the efficient conversion of pentose sugars, many kinds of microorganisms have been investigated to ferment xylose to ethanol. P. stipitis and Candida shehatae were reported to use xylose efficiently than other yeasts [5]. Moreover, P. stipitis was reported to produce more ethanol from xylose than $C$. shehatae. Among the xylose fermenting yeasts, $P$. stipitis was reported to be the most effective strain because of its high ethanol yield $[3,5]$.

In an attempt to produce ethanol from lignocellulosic bio- 
mass, we studied the way of efficient fermentation with glucose and/or xylose. Considering the characteristics of two yeast strains, different culture conditions such as separated, $\mathrm{co}^{-}$culture and sequential fermentation of different yeasts, and the effect of yeast nitrogen base (YNB) were investigated.

\section{Materials and Methods}

Yeast strains and media

S. cerevisiae strain was obtained from an industrial source, baker's dry yeast (Cho Heung, Ansan, Kyungkido, Korea) and $P$. stipitis was obtained from Korea Biological Resource Center (KCTC 7228; ATCC 58784). S. cerevisiae was grown and maintained on $1.5 \%$ agar plate containing YPD (yeast peptone dextrose; $10 \mathrm{~g} / 1$ yeast extract, $20 \mathrm{~g} / 1$ peptone, 30 $\mathrm{g} / 1$ glucose and $20 \mathrm{~g} / 1$ agar) media at $37^{\circ} \mathrm{C}$ and P. stipitis was grown at $30^{\circ} \mathrm{C}$ and maintained on YPX (yeast peptone xylose) media agar plate which has same ingredients with YPD media except $30 \mathrm{~g} / 1$ xylose instead of glucose. Glucose (30 g/l or $60 \mathrm{~g} / \mathrm{l})$ and xylose media $(30 \mathrm{~g} / \mathrm{l}$ or $60 \mathrm{~g} / \mathrm{l})$ for main culture were prepared separately and $60 \mathrm{~g} / \mathrm{l}$ of glucose and xylose media were mixed to make $30 \mathrm{~g} / 1$ glucose -30 $\mathrm{g} / 1$ xylose mixed medium ( $60 \mathrm{~g} / 1$ total sugar concentration). The concentrations of glucose, xylose and the mixture in medium were measured with high performance liquid chroma ${ }^{-}$ tography (HPLC) and the values were $29.4 \mathrm{~g} / 1$ glucose, 29.0 $\mathrm{g} / 1$ xylose and $54.6 \mathrm{~g} / 1$ mixed sugars. When glucose was depleted, the yeast nitrogen base (YNB, $5.0 \mathrm{~g} / 1\left(\mathrm{NH}_{4}\right)_{2} \mathrm{SO}_{4}$, $0.1 \mathrm{~g} / 1 \mathrm{KH}_{2} \mathrm{PO}_{4}, 0.5 \mathrm{~g} / 1 \mathrm{MgSO}_{4}, 0.1 \mathrm{~g} / 1 \mathrm{NaCl}, 0.1 \mathrm{~g} / 1 \mathrm{CaCl}_{2}$, amino acids, vitamins and trace elements, Difco, Detroit, MI, USA) was added to the medium to supply nutrients in fermentation at the concentration of $1.7 \mathrm{~g} / \mathrm{l}$.

\section{Fermentation conditions}

For pre-culture, colonies of $S$. cerevisiae from a maintained plate were grown in YPD (30 g/l of glucose) media overnight in a $50 \mathrm{ml}$ Erlenmeyer flask at $37^{\circ} \mathrm{C}, 180 \mathrm{rpm}$ and $P$. stipitis were grown in YPX ( $30 \mathrm{~g} / 1$ of xylose) media at $30^{\circ} \mathrm{C}$, $180 \mathrm{rpm}$. Both yeasts were pre-cultivated overnight above $\mathrm{OD}_{600}=5$ and the cultured broth was took out with desired volume and centrifuged at 3,000 rpm for $10 \mathrm{~min}$. The centrifuged cell pellet was resuspended with fresh media and then inoculated to a main fermentation medium to be 0.5 of $\mathrm{OD}_{600}$ at initial point. Fermentation was performed in sterile 100 $\mathrm{ml}$ Erlenmeyer flasks with $50 \mathrm{ml}$ working volume. S. cer- evisiae was grown at $37^{\circ} \mathrm{C}$ under anaerobic condition (with air trap filled with $0.1 \mathrm{~N} \mathrm{HCl}$ ), whereas $P$. stipitis was grown at $30^{\circ} \mathrm{C}$ with an agitation speed of $100 \mathrm{rpm}$ in a shaking incubator. Fermentation profiles shown in figures are from one representative fermentation.

Analytical methods

Fermentation was monitored for 6 days by taking $1 \mathrm{ml}$ of samples and the samples were centrifuged at 12,000 rpm for $10 \mathrm{~min}$ then the supernatants were filtered with a 0.2 um syringe filter (Sartorius stedim biotech, Minisart RC 15). The concentrations of sugars and ethanol were determined using a HPLC (Young Lin CO., Korea) system equipped with Aminex HPX-87H column (BIO-RAD, CA, USA), and a BIO-RAD Cation $\mathrm{H}$ refill guard column and a refractive index detector (RID; Model LY9170, Young Lin CO., Korea). The mobile phase was $0.0017 \mathrm{~N} \mathrm{H}_{2} \mathrm{SO}_{4}$ and its flow rate and injection volume were $0.6 \mathrm{ml} / \mathrm{min}$ and $20 \mu \mathrm{l}$ at $35{ }^{\circ} \mathrm{C}$ of oven temperature. The serial concentration of standards for glucose and xylose were prepared with a five point calibration $(0,1.25,2.5,5$, and $10 \mathrm{~g} / \mathrm{l})$ and ethanol was prepared with four point $(0,12.5,25$, and $50 \mathrm{~g} / \mathrm{l})$ with $\mathrm{R}^{2}>0.999$. The cell concentrations were determined by optical density with a UV-Vis spectrophotometer (Amersham, ultrospec 2100pro) at $600 \mathrm{~nm}$. Yield was calculated as produced ethanol concentration divided by initial sugar concentration.

\section{Results}

Fermentation of glucose or xylose by $S$. cerevisiae or P. stipitis

To see whether $S$. cerevisiae and $P$. stipitis can use glucose or xylose to produce ethanol, batch cultures were carried out using S. cerevisiae or P. stipitis alone. The glucose fermentation by $S$. cerevisiae proceeds by a reduction of oxygen availability and $P$. stipitis has best rate of ethanol production under oxygen-limited conditions [9]. Anaerobic cultivations for S. cerevisiae were conducted $100 \mathrm{ml}$ Erlenmeyer flasks with air trap filled with $0.1 \mathrm{~N} \mathrm{HCl}$ and microaerobic cultivation for $P$. stipitis were preformed with sillistoppers.

All glucose was consumed by $S$. cerevisiae after $24 \mathrm{hr}$ of fermentation, and the ethanol concentration was $14.5 \mathrm{~g} / \mathrm{l}$ with a yield of $0.49 \mathrm{~g} / \mathrm{g}$ (Fig. 1A). However, xylose was hardly fermented by $S$. cerevisiae producing little amount of ethanol and the growth of cell was not significantly increased (Fig. 1B). P. stipitis consumed not only glucose but 

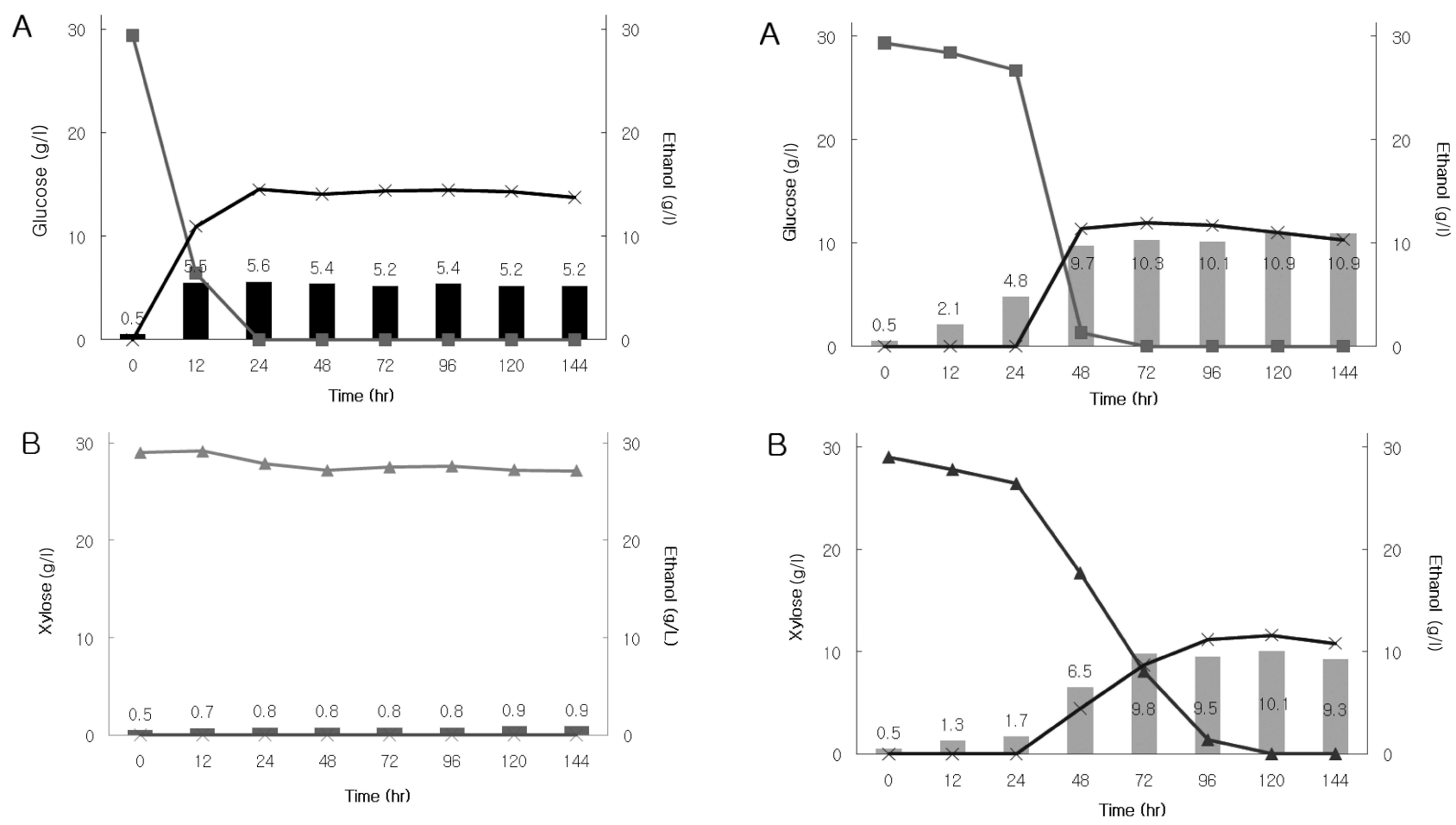

Fig. 1. Glucose or xylose fermentation by $S$. cerevisiae. A: S. cerevisiae was cultured in YPD (29.4 g/l glucose) media at $37^{\circ} \mathrm{C}$ under anaerobic condition with air trap filled with $0.1 \mathrm{~N} \mathrm{HCl}$. B: S. cerevisiae was cultured in YPX (29.0 g/1 xylose) media at $37^{\circ} \mathrm{C}$ under anaerobic condition with air trap filled with $0.1 \mathrm{~N} \mathrm{HCl}$. Symbols: glucose (--), ethanol (־), and $\mathrm{OD}_{600}$ for $S$. cerevisiae ( with OD value).

also xylose, producing ethanol. The glucose was slowly consumed by $P$. stipitis until $24 \mathrm{hr}$, and after then was rapidly consumed and depleted at $72 \mathrm{hr}$, producing $11.9 \mathrm{~g} / \mathrm{l}$ ethanol (Fig. 2A). The yield was low $(0.40 \mathrm{~g} / \mathrm{g})$, compared to $S$. cer $^{-}$ evisiae $(0.49 \mathrm{~g} / \mathrm{g})$. P. stipitis slowly utilized xylose until 24 $\mathrm{hr}$ and after then utilized it at higher speed. All the xylsoe was consumed by $96 \mathrm{hr}$. The maximum production of ethanol $(11.6 \mathrm{~g} / 1$ ethanol, yield $0.40 \mathrm{~g} / \mathrm{g})$ did not show differences with that of glucose by P. stipits (Fig. 2B).

Fermentation of mixture of glucose and xylose by S. cerevisiae and/or P. stipitis

As shown in xylose fermentation by S. cerevisiae (Fig. 1B), $S$. cerevisiae hardly used xylose in mixture with glucose as well but consumed glucose rapidly by $24 \mathrm{hr}$ and produced $13.4 \mathrm{~g} / \mathrm{l}$ ethanol at $72 \mathrm{hr}$ at its maximum with a yield of $0.25 \mathrm{~g} / \mathrm{g}$ (Fig. 3A). P. stipitis, on the contrary, consumed the glucose completely at $48 \mathrm{hr}$, and then xylose fermentation was started. P. stipitis produced $21.0 \mathrm{~g} / \mathrm{l}$ ethanol with a yield

Fig. 2. Glucose or xylose fermentation by $P$. stipitis. A: P. stipitis was cultured in YPD $(29.4 \mathrm{~g} / 1$ glucose $)$ media at $30^{\circ} \mathrm{C}$, $100 \mathrm{rpm}$ in a shaking incubator under microaerobic condition. B: P. stipitis was cultured in YPX $\left(29.0 \mathrm{~g} / 1 \mathrm{xy}^{-}\right.$ lose) media at $30^{\circ} \mathrm{C}, 100 \mathrm{rpm}$ in a shaking incubator under microaerobic condition. Symbols: xylose $(\leftarrow)$, ethanol $(\leftarrow)$, and $\mathrm{OD}_{600}$ for P. stipitis ( $\square$ with OD value).

of $0.38 \mathrm{~g} / \mathrm{g}$ (Fig. 3B). The utilization of glucose and xylose showed same trends with the previous results (Fig. 2). P. stipitis produced $11.9 \mathrm{~g} / \mathrm{l}$ ethanol in glucose only (Fig. 2A) and $11.4 \mathrm{~g} / \mathrm{l}$ ethanol in the mixture of glucose and xylose at $48 \mathrm{hr}$ when it consumed glucose completely. The ethanol concentration went up to $21.0 \mathrm{~g} / \mathrm{l}$ at $120 \mathrm{hr}$ fermentation. Considering the ethanol yield from xylose by $P$. stipitis (11.6 $\mathrm{g} / \mathrm{l}$ at $120 \mathrm{hr}$ ), the reasonable amount (11.4g/l ethanol from glucose and $9.6 \mathrm{~g} / \mathrm{l}$ ethanol from xylose) of ethanol was produced.

The co-culture fermentation with simultaneous inoculation of both yeasts produced $18.6 \mathrm{~g} / \mathrm{l}$ ethanol at its maximum at $144 \mathrm{hr}$ with a yield of $0.34 \mathrm{~g} / \mathrm{g}$ and the time reaching to the maximum ethanol concentration was $\mathrm{de}^{-}$ layed compared to previous results (Fig. 4). The yield was higher compared to the fermentation with single $S$. cerevisiae $(0.24 \mathrm{~g} / \mathrm{g})$ but slightly lower compared to that with single P. stipitis (0.38 g/g) (Fig. 3). 

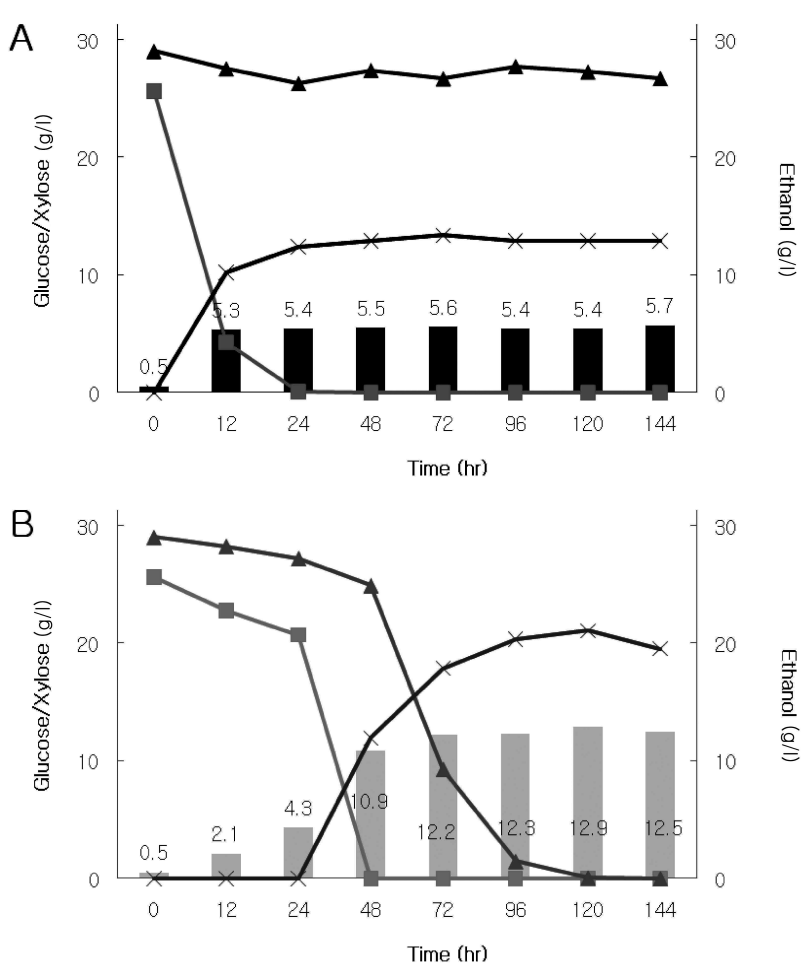

Fig. 3. Fermentation of mixture of glucose and xylose by S. cerevisiae or P. stipitis in sepatated fermentation. A: S. cerevisiae was cultured in the mixture of YPD $(29.4 \mathrm{~g} / 1 \mathrm{glu}-$ cose) and YPX ( $29.0 \mathrm{~g} / 1$ xylose) media at $37^{\circ} \mathrm{C}$ under anaerobic condition with air trap filled with $0.1 \mathrm{~N} \mathrm{HCl}$. B: P. stipitis was cultured in the mixture of media (29.4 $\mathrm{g} / \mathrm{l})$ and YPX $(29.0 \mathrm{~g} / \mathrm{l})$ media at $30^{\circ} \mathrm{C}, 100 \mathrm{rpm}$ in a shaking incubator under microaerobic condition.

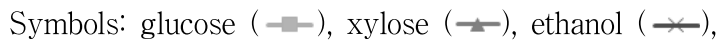
$\mathrm{OD}_{600}$ for $S$. cerevisiae ( with $\mathrm{OD}$ value) and $\mathrm{OD}_{600}$ for P. stipitis ( $\square$ with OD value).

\section{Sequential fermentation and effects of nutrients}

Sequential fermentation was carried out to compare the production of ethanol with that of $\mathrm{co}^{-}$culture with both yeasts. Because glucose decreased to zero around $24 \mathrm{hr}, P$. stipitis inoculated at $24 \mathrm{hr}$ after removing $S$. cerevisiae by centrifugation. First of all, glucose seemed to be consumed by $S$. cerevisiae before $24 \mathrm{hr}$, producing $12.4 \mathrm{~g} / \mathrm{l}$ ethanol at its maximum with a yield of $0.23 \mathrm{~g} / \mathrm{g}$ but xylsoe was not utilized . After reaching high concentration of ethanol prodution, it decreased slowly to $10.4 \mathrm{~g} / \mathrm{l}$ ethanol until $144 \mathrm{hr}$ (Fig. 5A). Compared to co-culture, concentration of ethanol product was lower (18.58 g/l ethanol; yield of $0.35 \mathrm{~g} / \mathrm{g}$ ). We suspected that $S$. cerevisiae depleted essential nutrients during making ethanol from glucose so the nutrients for $P$. stipitis was not enough to make ethanol from xylose.

To improve the abilities of xylose fermentation by P. stip-

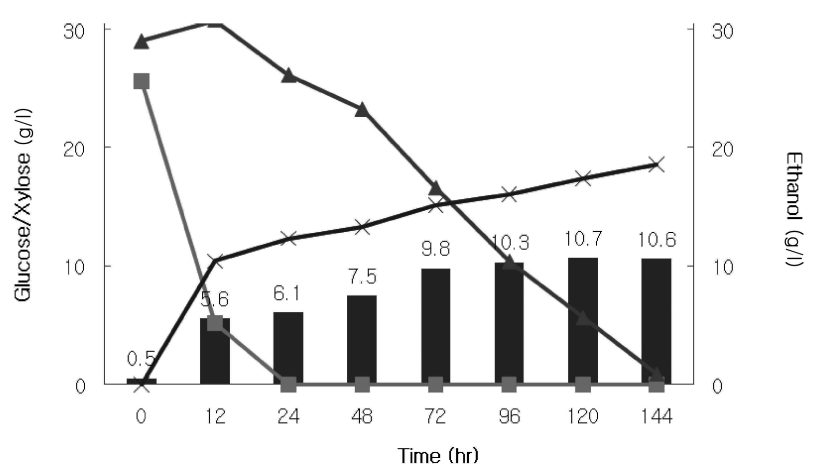

Fig. 4. Fermentation of mixture of glucose and xylose by S. cerevisiae and $P$. stipitis in co-culture fermentation. Both $S$. cerevisiae and $P$. stipitis were cultured in the mixture of YPD (29.4 g/l glucose) and YPX ( $29.0 \mathrm{~g} / 1$ xylose) media at $37^{\circ} \mathrm{C}$ under anaerobic condition with air trap filled with $0.1 \mathrm{~N} \mathrm{HCl}$. After $24 \mathrm{hr}$, the air trap was replaced by a sillistopper to make microaerobic condition at $30^{\circ} \mathrm{C}$, $100 \mathrm{rpm}$ in a shaking incubator. Symbols: glucose $(--)$, xylose $(-)$, ethanol $(\longleftarrow), \mathrm{OD}_{600}$ for $S$. cerevisiae and P. stipitis ( with OD value).

itis, the yeast nitrogen base (YNB) was added to the mixed media as nutrients after removing $S$. cerevisiae at $24 \mathrm{hr}$. The growth of cell was increasing up to $\mathrm{OD}_{600}$ of 13.2 after adding YNB. In contrast to the result without nutrients (YNB), the concentration of xylose reached zero at $120 \mathrm{hr}$ and ethanol was produced as much as $22.5 \mathrm{~g} / 1$ with a yield of 0.41 g/g (Fig. 5B).

\section{Discussion}

S. cerevisiae is used for industrial ethanol production because it is highly effective on the production of ethanol from hexose sugars and has high tolerance to ethanol and other inhibitory compounds [10-12]. However, it is unable to convert xylose to ethanol efficiently, because of the absence or the low activity of key enzymes involved in xylose catabolism $[3,18]$. Moreover, when cultivated on glucose, the productivity of ethanol by $S$. cerevisiae is 5 times higher than that of xylose-fermenting yeast on glucose or xylose [4]. Our results showed that glucose was easily fermented by $S$. cerevisiae, because glucose is the most preferred substrate (Fig. 1) as reported previously [15]. Glucose was completely consumed after $24 \mathrm{hr}$ of fermentation producing $14.5 \mathrm{~g} / \mathrm{l}$ ethanol while xylose was hardly utilized by $S$. cerevisiae.

Some microorganisms can utilize pentose sugars efficiently [1]. Among them, $P$. stipitis is more suitable microorganism, having great potential and broad substrate specif- 

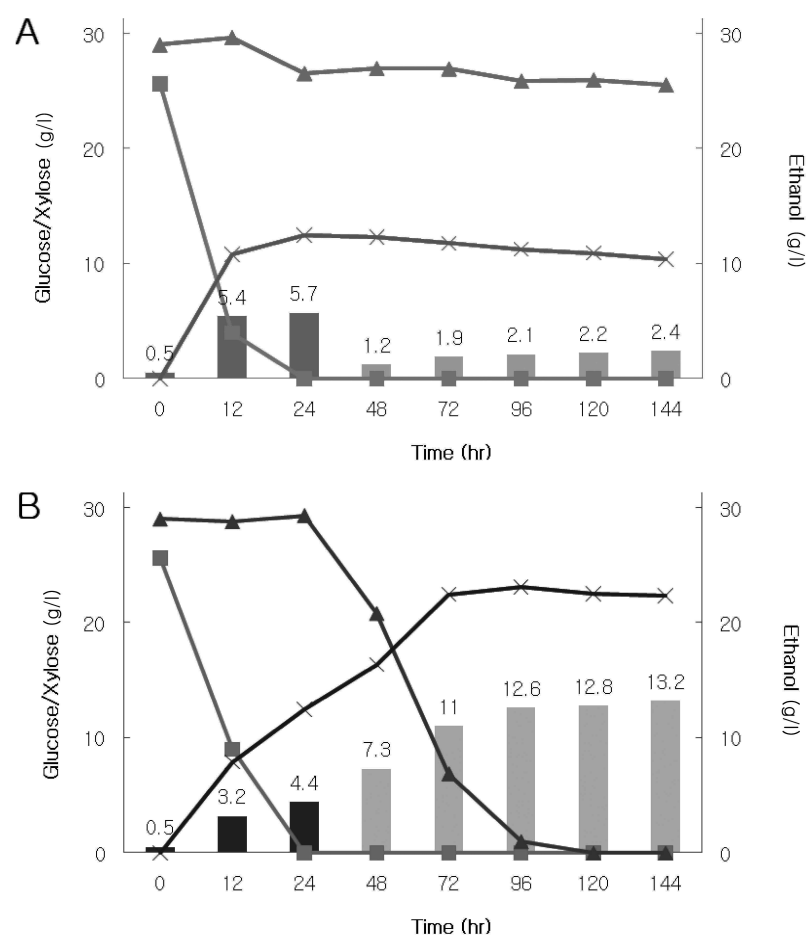

Fig. 5. Sequential fermentation by $S$. cerevisiae and $P$. stipitis. $S$. cerevisiae was cultured in the mixture of YPD (29.4 $\mathrm{g} / 1$ glucose $)$ and YPX (29.0 g/1 xylose) media at $37^{\circ} \mathrm{C}$ under anaerobic condition with air trap filled with 0.1 $\mathrm{N} \mathrm{HCl}$. After $24 \mathrm{hr}$, the medium was centrifuged to remove $S$. cerevisiae and then $P$. stipitis was inoculated to the supernatant without yeast nitrogen base (YNB) or with YNB and cultured at $30^{\circ} \mathrm{C}, 100 \mathrm{rpm}$ in a shaking incubator under microaerobic condition. A: without YNB. B: with YNB. Symbols: glucose $(--)$, xylose $(\leftarrow)$, ethanol $(\longleftarrow), \mathrm{OD}_{600}$ for $S$. cerevisiae ( with $\mathrm{OD}$ value) and $\mathrm{OD}_{600}$ for $P$. stipitis ( with $\mathrm{OD}$ value).

icity for pentose utilization [16]. In glucose medium, $P$. stipitis completed fermentation by $48 \mathrm{hr}$ producing $11.9 \mathrm{~g} / \mathrm{l}$ ethanol with yield $0.40 \mathrm{~g} / \mathrm{g}$ while it completed fermentation by $96 \mathrm{hr}$ in xylose medium, producing $11.6 \mathrm{~g} / \mathrm{l}$ ethanol with yield $0.40 \mathrm{~g} / \mathrm{g}$. The yields were similar to results of Agbogbo et al [2]. In the growth of cell, the growth of $P$. stipitis was slightly higher in glucose medium than in xylose medium (Fig. 2) as reported by Meyrial et al [13].

Because of the repression of xylose uptake by glucose, glucose is the most preferred substrate and consumed before xylose fermentation started [15]. S. cerevisiae can utilize the glucose but not xylose to make ethanol while $P$. stipitis consumed xylose after using glucose. Taniguchi et al reported that $\mathrm{CO}^{-}$culture system is useful with sugar mixture where potential glucose-fermenting yeast is cultivated with $\mathrm{xy}^{-}$ lose-fermenting yeast. In our experiment, ethanol concentration at the end of fermentation was $18.6 \mathrm{~g} / \mathrm{l}$ (yield 0.34 $\mathrm{g} / \mathrm{g}$ ) in the $\mathrm{co}^{-}$culture fermentation and $12.4 \mathrm{~g} / \mathrm{l}$ (yield 0.23 $\mathrm{g} / \mathrm{g})$ in the sequential fermentation. It seems that the $\mathrm{co}^{-} \mathrm{cul}^{-}$ ture fermentation produced ethanol more efficiently than $\mathrm{se}^{-}$ quential fermentation. Surely in this study, $\mathrm{co}^{-}$culture was better than the sequential fermentation in ethanol production if YNB was not added. However, the sequential fermentation was better to make more ethanol when YNB was added, although YNB never contained any sugar to be converted into ethanol. Even though $P$. stipitis does not need vitamin requirements for xylose fermentation and can utilize a wide range of sugars [14,16], when YNB was added to the mixture fermentation, the cell growth rate, consumption of each sugar and ethanol productivity were increased compared to $\mathrm{CO}^{-}$culture fermentation. Because $\mathrm{YNB}$ is expensive nutrient for the industrial usage, the component which supplemented the nutrient for $P$. stipitis needs to be elucidated. In addition, lignocellulosic biomass has many additional nutrients which are different from YPD or YPX media, the culture systems developed in this study needs to be applied in a real lignocelluose hydrolysate.

In the present study, $S$. cerevisiae did not ferment xylose but $P$. stipitis fermented both glucose and xylose to produce ethanol. $P$. stipitis fermented the mixture of glucose and $\mathrm{xy}^{-}$ lose while $S$. cerevisiae fermented only glucose. The $\mathrm{co}^{-} \mathrm{cul}^{-}$ ture fermentation had more efficient ethanol productivity than the sequential fermentation without YNB. However, the sequential fermentation with YNB was the most efficient way of ferment both sugars to ethanol. After depleting glucose, $P$. stipitis seemed to utilize xylose continuously with addition of YNB instead of using ethanol as carbon resource, producing more ethanol. In application of ethanol production using lignocelluloses biomass, it is desirable to convert glucose to ethanol by $S$. cerevisiae then inoculate $P$. stipitis with additional nutrients to convert xylose to ethanol.

\section{References}

1. Abbi, M., R. C. Kuhad, and A. Singh. 1996. Bioconversion of pentose sugars to ethanol by free and immobilized cells of Candida shehatae (NCL-3501): Fermentation behaviour. Process Biochem. 31, 555-560.

2. Agbogbo, F. K., G. Coward-Kelly, M. Torry-Smith, and K. S. Wenger. 2006. Fermentation of glucose/xylose mixtures using Pichia stipitis. Process Biochem. 41, 2333-2336.

3. Batt, C. A., S. Caryallo, D. D. Easson, M. Akedo, and A. 
J. Sinskey. 1986. Direct evidence for a xylose metabolic pathway in Saccharomyces cerevisiae, pp. 549-553, Wiley Subscription Services, Inc., A Wiley Company.

4. Chandrakant, P. and V. S. Bisaria. 1998. Simultaneous Bioconversion of Cellulose and Hemicellulose to Ethanol. CRC Crit. Rev. Biotechnol. 18, 295-331.

5. du Preez, J. C. and B. A. Prior. 1985. A quantitative screening of some xylose-fermenting yeast isolates. Biotech. Lett. 7, 241-246.

6. Goldemberg, J. and T. B. Johansson. 2004. World Energy Assessment: Overview 2004 Update. United Nations Development Programme.

7. Gupta, R., K. K. Sharma, and R. C. Kuhad. 2009. Separate hydrolysis and fermentation (SHF) of Prosopis juliflora, a woody substrate, for the production of cellulosic ethanol by Saccharomyces cerevisiae and Pichia stipitis-NCIM 3498. Bioresource Technol. 100, 1214-1220.

8. Jeffries, T. W. and C. P. Kurtzman. 1994. Strain selection, taxonomy, and genetics of xylose-fermenting yeasts. Enzyme Micro. Technol. 16, 922-932.

9. Ligthelm, M. E., B. A. Prior, and J. C. Preez. 1988. The oxygen requirements of yeasts for the fermentation of $\mathrm{d}$-xylose and d-glucose to ethanol. App. Microb. Biotechnol. 28, 63-68.

10. Lin, Y. and S. Tanaka. 2006. Ethanol fermentation from biomass resources: current state and prospects. Appl. Microbiol. Biotechnol. 69, 627-642.

11. Matsushika, A. and S. Sawayama. 2008. Efficient bioethanol production from xylose by recombinant saccharomyces cerevisiae requires high activity of xylose reductase and moderate xylulokinase activity. J. Biosci. Bioeng. 106, 306-309.

12. Matsushika, A., S. Watanabe, T. Kodaki, K. Makino, and S. Sawayama. 2008. Bioethanol production from xylose by recombinant Saccharomyces cerevisiae expressing xylose reductase, $\mathrm{NADP}+-$ dependent xylitol dehydrogenase, and xylulokinase. J. Biosci. Bioeng. 105, 296-299.

13. Meyrial, V., J. P. Delgenes, C. Romieu, R. Moletta, and A. M. Gounot. 1995. Ethanol tolerance and activity of plasma membrane ATPase in Pichia stipitis grown on xylose or on glucose. Enzyme Microb. Technol. 17, 535-540.

14. Nigam, J. 2001. Development of xylose-fermenting yeast Pichia stipitis for ethanol production through adaptation on hardwood hemicellulose acid prehydrolysate. J. App. Microb. 90, 208-215.

15. Panchal, C. J., L. Bast, I. Russell, and G. G. Stewart. 1988. Repression of xylose utilization by glucose in $\mathrm{xy}^{-}$ lose-fermenting yeasts. Can. J. Microbiol. 34, 1316-1320.

16. Preez, J. C., M. Bosch, and B. A. Prior. 1986. The fermentation of hexose and pentose sugars by Candida shehatae and Pichia stipitis. Appl. Microbiol. Biotechnol. 23, 228-233.

17. Taniguchi, M., T. Tohma, T. Itaya, and M. Fujii. 1997. Ethanol production from a mixture of glucose and xylose by $\mathrm{CO}^{-}$culture of Pichia stipitis and a respiratory-deficient mutant of Saccharomyces cerevisiae. J. Fermen. Bioeng. 83, 364-370.

18. Van Zyl, C., B. A. Prior, S. G. Kilian, and J. L. F. Kock. 1989. D-Xylose Utilization by Sacharomyces cerevisiae. J. Gen. Microbiol. 135, 2791-2798.

19. Wall, J. D., C. S. Harwood, and A. Demain. 2008. BIOENERGY. pp. 3-6, ASM Press, Washington. DC.

20. Williams, R. H. 1997. Methanol and hydrogen from biomass for transportation with comparisons to methanol and hydrogen from natural gas and coal. Fuel Energy 38, 78-79.

21. Yoon, G. S., T. S. Lee, C. Kim, J. H. Seo, and Y. W. Ryu. 1996. Characterization of Alchol Fermentation and Segregation of Protoplast Fusant of Saccharomyces cerevisiae and Pichia stipitis. J. Microbiol. Biotechnol. 6, 286-291.

\section{초록: Saccharomyces cerevisiae와 Pichia stipitis를 이용한 오탄당과 육탄당으로부터 에탄올 생 산에 관한 비교연구}

김중곤 ${ }^{*}$ 안정훈 ${ }^{*}$

( ${ }^{1}$ 부산대학교 나노융합기술학과, ${ }^{2} \mathrm{KAIST}$ 부설 한국과학영재학교)

포도당과 자일로스는 자연계에서 가장 풍부한 물질이며 이들은 효모에 의해 에탄올로 전환될 수 있다. 본 연구에서 는 Saccharomyces cerevisiae와 Pichia stipitis을 이용하여 분리배양, 공동배양 그리고 순차배양 등의 조합을 통해 가장 효 과적인 발효의 방법을 찾고자 하였다. 분리배양에서 S. cerevisiae은 $29.4 \mathrm{~g} / 1$ 의 포도당을 발효하여 $14.5 \mathrm{~g} / 1$ 의 에탄올을 생산한 반면에 자일로스를 이용하지 못했다. 그렇지만 P. stipitis은 포도당뿐만 아니라 자일로스도 분해하여 각각 포도 당 $29.4 \mathrm{~g} / 1$ 로부터 $11.9 \mathrm{~g} / 1$ 의 에탄올을, 자일로스 $29.0 \mathrm{~g} / 1$ 로부터 $11.6 \mathrm{~g} / 1$ 의 에탄올을 생산하였다. 포도당과 자일로스 혼합배양에서, S. cerevisiae은 $13.4 \mathrm{~g} / 1$ 의 에탄올을 생산한 반면에 P. stipitis은 $21.1 \mathrm{~g} / 1$ 의 에탄올을 생산하였다. 공동배양 과 순차배양에서, 공동배양이 $18.6 \mathrm{~g} / \mathrm{l}$, 순차배양이 $12.4 \mathrm{~g} / 1$ 의 에탄올을 생산하여 공동배양이 더 효과적인 것으로 나타 났다. 두 효모의 생장에서 영양분의 효과를 보기 위해 yeast nitrogen base (YNB)을 S. cerevisiae가 포도당을 소모한 시 점에 첨가하니 자일로스의 소비량과 미생물의 성장이 증가하였고 $54.6 \mathrm{~g} / 1$ 의 당 혼합배양액에서 $22.5 \mathrm{~g} / 1$ 의 에탄올을 생산하여 $0.41 \mathrm{~g} / \mathrm{g}$ 의 수득율을 나타내었다. 